GEOLOGICA BALCANICA 50 (2), Sofia, August 2021, pp. 47-51.

\title{
Review of investigations into the vadose zone's variable state of saturation in connection with the assessment of radon potential in Bulgaria
}

\author{
Bistra Kunovska ${ }^{1}$, Mila Trayanova ${ }^{2}$, Monika Mutovska ${ }^{1}$, Simeon Valchev², \\ Boyka Mihaylova ${ }^{2}$
}

${ }^{1}$ National Center for Radiobiology and Radiation Protection, 3 St Georgi Sofiyski Str., 1606 Sofia, Bulgaria; e-mails: b.kunovska@ncrrp.org; m.mutovska@ncrrp.org

${ }^{2}$ Geological Institute, Bulgarian Academy of Sciences, Acad. G. Bonchev Str., Bl. 24, 1113 Sofia, Bulgaria;

e-mails: milatr@abv.bg; simeonwaltscheff@abv.bg; mihaylovaboyka@gmail.com

(Received: 07 June 2021; accepted in revised form: 23 July 2021)

\begin{abstract}
Natural radon $\left({ }^{222} \mathrm{Rn}\right)$ is a radioactive noble gas that occurs as the immediate decay product of radium $\left({ }^{226} \mathrm{Ra}\right)$, part of the ${ }^{238} \mathrm{U}$ family, in the lithosphere. Radon is driven by advection and diffusion with soil gas throughout connected and water-unsaturated pores and/or cracks in permeable rocks and soils. The aim of the present study is to do a review of the existing so far research activities in Bulgaria in connection with the observation and/or evaluation of the degree of water saturation of the near-surface layer, and on that base to distinguish the up-to-date achievements in regards to the radon potential in situ evaluation. Due to this review, the studies in Bulgaria concerning moisture dynamics in the near-surface layers can be divided mainly into two groups. The first one investigates the hydraulic characteristics (parameters) of soils in the vadose zone. Based on that, conclusions or computer simulations for the saturation degree estimation can be drawn. The other group includes in situ observations by sensors on the change of moisture with time. The results of these studies may serve as a base for more precise moisture dynamics assessment at sites with specific radon potential tendencies.
\end{abstract}

Kunovska, B., Trayanova, M., Mutovska, M., Valchev, S., Mihaylova, B. 2021. Review of investigations into the vadose zone's variable state of saturation in connection with the assessment of radon potential in Bulgaria. Geologica Balcanica 50 (2), 47-51.

Keywords: hydrogeology, moisture dynamics, environment, hydraulic parameters, regional studies.

\section{INTRODUCTION}

Natural radon $\left({ }^{222} \mathrm{Rn}\right)$ is a radioactive noble gas that occurs as the immediate decay product of radium $\left({ }^{226} \mathrm{Ra}\right)$, part of the ${ }^{238} \mathrm{U}$ family, in the geological environment (lithosphere). It is also connected with the decay of natural uranium, found to varying degrees in a wide range of rocks and soils, and in building materials. Different types of rocks and soils possess different ${ }^{226} \mathrm{Ra}$ content, therefore ra- don concentrations vary in the near surface field. Radon has high mobility and is driven by diffusion and convection with soil gas throughout connected and water-unsaturated pores and/or cracks in permeable rocks and soils - processes described in several review articles (e.g., Etiope and Martinelli, 2002; Appleton and Miles, 2010). In this regard, the physical characteristics of soil's layers, especially its permeability, can also affect the flow of ${ }^{222} \mathrm{Rn}$ (Porstendörfer, 1994; Nazaroff et al., 1998). There- 
fore, the radon potential of an area, which describes the probability of high indoor radon concentration, could be dependent on not only the geological make-up as a constant source of radon but also the changes of the saturation state of the ground. Thus, there is a need for systematic review of the existing studies concerning the moisture dynamics in the near-surface geoenvironment from the viewpoint of radon potential impact.

In respect to the radon potential and moisture content of the medium, certain relationships have been observed (e.g., Pinault and Bauron, 1996). In accordance with the large field area relationships, two tendencies have been reported (Sakoda et al., 2011). The first one represents results that concern the increase in radon potential with the increase in moisture content of the media (Arvela et al., 2016). In this case, the geological medium is represented by granites and similar magmatic rocks, i.e., potentially fractured rocks. The second tendency shows that the increase in water content in sedimentary rocks and soils leads to a decrease in radon potential, i.e., so-called "screening effect" (Jönsson, 2001; Sakoda et al., 2011).

In Bulgaria, studies concerning the measurement of radon in particular geomorphological units and/or evaluation of the radon potential, applying the different approaches over the whole territory, are being done nowadays (Ivanova et al., 2019; Antonov et al., 2020; Nojarov et al., 2020; Turek et al., 2020). At the moment, there is a lack of detailed investigation of the near-surface hydrogeology from the viewpoint of radon potential and moisture content tendencies and relationships. An initial step in that direction was made by Valchev et al. (2020). The aim of the present study is to review the existing so far research activities in Bulgaria in connection with the observation and/or evaluation of the degree of water saturation of the near-surface layer, and on that base to distinguish the up-to-date achievements in regards to the radon potential in situ evaluation.

\section{THEORETICAL REMARKS}

For radon transport, especially for long distance migration into soils or sedimentary rocks, gas permeability should be considered as the dominant parameter because advection is generally more important than diffusion (Neznal et al., 2004; Neznal and Neznal, 2005; Barnet et al., 2008, 2019; Lucchetti et al., 2019).

In the unsaturated zone, liquid and gas advective fluxes are described by Darcy's law, assuming there is no interaction between those fluids. Thus, the presence of both fluids decreases the cross-sectional area available for the flow of each fluid, and its permeability, with respect to that fluid, decreases (Benavente et al., 2019). Hence, soil water content directly affects gas permeability, and therefore the radon transport and its eventual presence near the ground surface, especially the weather factors (mainly rainfall), have been considered (Fig. 1).

More theoretical notes about gas and water permeability, moisture content, including hydraulic functions and parameterization, could be found in Schanz et al. (2011), Nguyen-Tuan et al. (2014), and Benavente et al. (2019). In addition, the latter research proposed a methodology that estimates gas permeability based on soil texture (by using the socalled pedotransfer function (PTF) analysis based on translation of basic soil data into hydraulic properties) and water content with direct application of the radon studies.

\section{REVIEW OF BULGARIAN RESEARCH ACTIVITIES}

In Bulgaria, hydrogeological and hydraulic investigations of the near-surface medium have been in progress since the middle of the last century. However, they have to be summarized and analyzed from the viewpoint of radon potential investigations. Special attention is given to particular studies that allow implementation of their results for the assessment of soils' saturation state directly or by modeling. The studies concerning moisture dynamics in the near-surface layers may mainly be divided into two groups: the first one investigates the hydraulic characteristics (parameters) of the soils in the vadose zone. Based on that, some conclusions or even computer simulations for the saturation degree estimation can be performed. The other group includes in situ observations (with sensors) on moisture variations in time.

The first published investigations dedicated to the first group of studies were done by Spassov (1966, 1969). In them, the problems of the approximate calculation of the natural movement of moisture in the zone of aeration based on three methods - tensiometric, centrifugation and adsorption (Spassov, 1966), and of the nature of the total soil moisture potential (Spassov, 1969) were discussed. The latter specifically concerns loess and argillaceous-sandy soils. It is not of a surprise as loess soils, being mostly an unsaturated zone, cover about $13 \%$ of the Bulgarian territory. The most recent investigations 


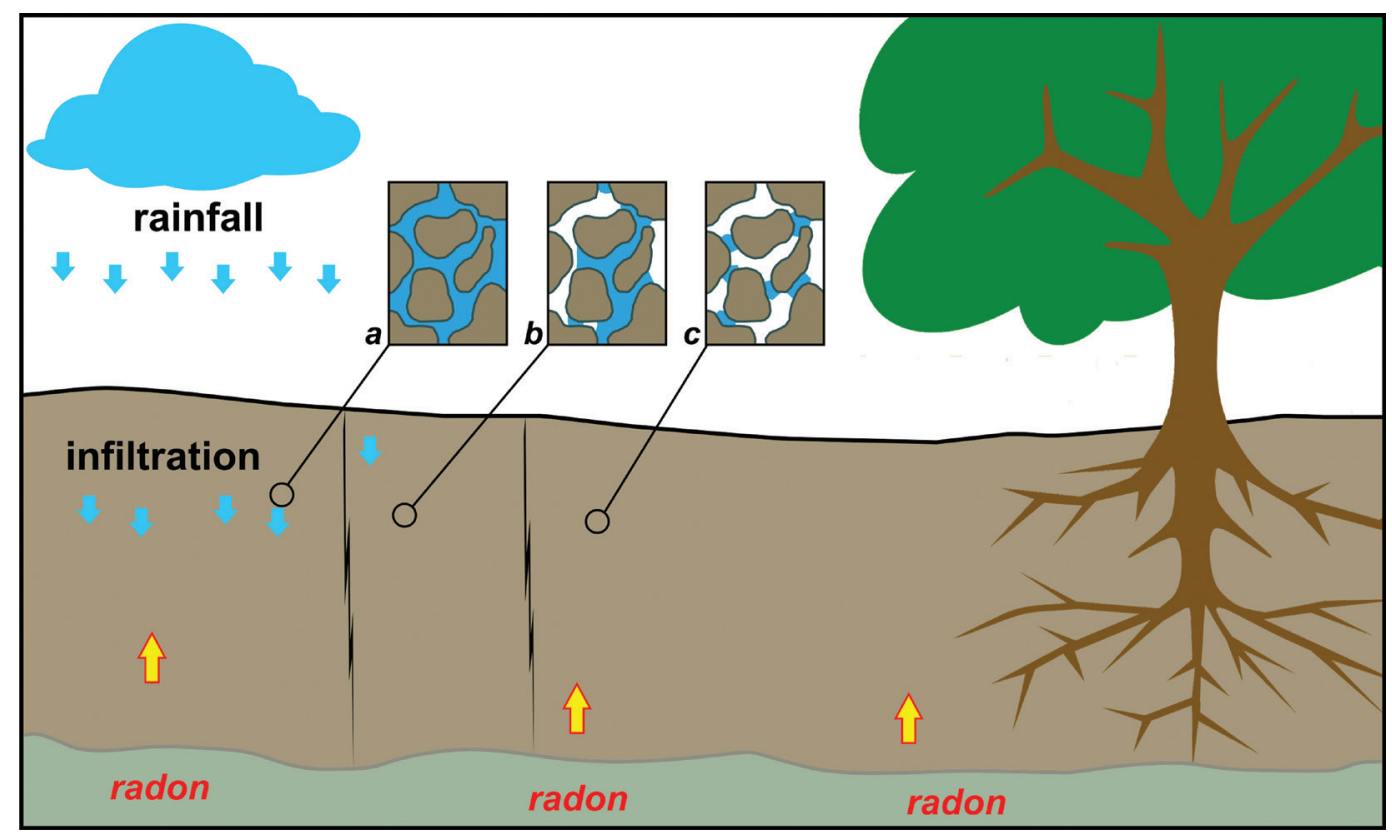

Fig. 1. Schematic spatial-temporal dependence of water and gas phases in unsaturated zone: $a$ ) zone of full water saturation, $b$ ) zone of temporally partial water saturation, $c$ ) steadily unsaturated zone.

connected to or describing the hydraulic characteristics of these soils are connected with the in situ field-scale soil hydraulic parameters derivated from all unsaturated layers in an area close to Kozloduy NPP by using large-scale infiltrometer tests (e.g., Mallants et al., 2007; Antonov et al., 2012). The second group concerns real-time observations on the moisture and matrix (suction) potential of the loess complex (Gerginov et al. 2018; Antonov et al. 2018a). In these studies, results having been obtained by sensors installed at three levels below the ground, tensiometers and sensors for soil moisture content are discussed.

The first group of studies also includes implementation of PTF's hydraulic characteristics as parameterization of the hydraulic characteristics of Bulgarian soils using the model of Van Genuchten, which is based on seven texture classes (Rousseva, 1997, 2001). Also to the first group belong computer modeling studies, implementing the pedotransfer function's hydraulic characteristics with regard to flow and pollutant transport in the loess complex (Stoyanov, 2009, 2012), the Ogosta River floodplain (Benderev et al., 2015; Antonov et al., 2018b; 2019), and central Bulgaria (Stoyanov, 2008, 2018). For the loess sediment investigations, estimation of the eventual transport of several radionuclides has been made. In the Ogosta River floodplain, the simulation results showed complete water saturation of the floodplain deposits at some of the arsenic polluted spots, while only the upper layers were saturated at other sites. Similarly to the above-mentioned loess sediment case, it was implemented an approach for simulations of contaminant transport in the research works for central Bulgaria. Connected with observations of moisture dynamics at the upper part of the soil profile are the studies presented by Kolev (2016) and Kotsev et al. (2020), discussing the surface-groundwater interaction at the region of Valche Dere, SW Bulgaria, and at the region of Chiprovtsi, NW Bulgaria, respectively.

Apart from these two groups, the data from several regional studies (i.e.., Tcherkezova, 2015; Sapundzhiev, 2016; Berov et al., 2017; Stoynev and Ivanov, 2019) could serve as a preliminary indicator of the possibility of near-surface field saturation. Tcherkezova (2015) examined the geomorphology (geomorphometric variables) and the possibility of long-term soil saturation near river valleys. Sapundzhiev (2016) evaluated the soil texture (physical clay per cent) on Bulgarian territory. The higher the clay content in soil, the more susceptible it is to saturation. Berov et al. (2017) and Stoynev and Ivanov (2019) summarized and analyzed the liquefaction events of water-saturated sediments for a long-term period in the history of Bulgaria. 


\section{CONCLUSION}

A review of the existing articles on moisture dynamics in Bulgaria show that main area of investigation is confined to North Bulgaria due to the widespread distribution of loess deposits. There are studies using computer models, which are based on a local floodplain soils' hydraulic characteristics that allow estimation of the daily or weekly variations of the soil saturation state. In addition, some regional works on soils susceptible to liquefaction, due to complete or almost complete saturation, exist. All these studies may serve as a base for further detailed investigation of the moisture dynamics at sites with specific radon potential tendencies.

\section{Acknowledgements}

This study is supported by the National Science Fund of Bulgaria, in the framework of Grant No KP-06-N37/22/07.12.2019. The authors are grateful to Assoc Prof. Petar Gerginov (Geological Institute, Bulgarian Academy of Sciences, Sofia) and Dr. Velimira Stoyanova (National Institute of Geophysics, Geodesy and Geography, Bulgarian Academy of Sciences, Sofia) for critical reviews and comments.

\section{REFERENCES}

Antonov, D., Karastanev, D., Mallants, D. 2012. Determination of soil hydrological parameters of a multi-layered loess complex using HYDRUS-2D and field infiltration experiments. Comptes rendus de l'Académie bulgare des Sciences 65 (12), 1717-1724.

Antonov, D., Orehova, T., Gerginov, P., Kolev, S. 2018a. Seasonal changes of the soil-water potential in loess deposits, Northeastern Bulgaria case. Review of the Bulgarian Geological Society 79 (3), 133-134.

Antonov, D., Nakamura, K., Kotsev, T., Stoyanova, V., Kretzschmar, R. 2018b. Application of Hydrus-1D for Evaluation of the Vadose Zone Saturation State in connection with Arsenic Mobilization and Transport in Contaminated River Floodplain - Ogosta Valley Case Study, NW Bulgaria. Proceedings of the $18^{\text {th }}$ International Multidisciplinary Scientific GeoConference "SGEM2018” 18 (1.2), 83-90, https:// doi.org/10.5593/sgem2018/1.2/S02.011.

Antonov, D., Kotsev, T., Benderev, A., Van Meir, N., Gerginov, P., Stoyanova, V., Tcherkezova, E. 2019. Estimating the moisture regime in variably-saturated arsenic contaminated alluvial sediments by using HYDRUS-1D with daily meteorological data. European Journal of Geography 10 (2), 42-55.

Antonov, D., Andreeva, P., Benderev, A., Ivanova, K., Kolev, S. 2020. Geology as a Factor of Radon Potential in Bulgaria. Proceedings of the $20^{\text {th }}$ International Multidisciplinary Scientific Geoconference SGEM2020 20 (1.1), 119-124, https://doi.org/10.5593/sgem2020/1.1/s01.015.

Appleton, J.D., Miles, J.C. 2010. A statistical evaluation of the geogenic controls on indoor radon concentrations and radon risk. Journal of Environmental Radioactivity 101 (10), 799-803, https://doi.org/10.1016/j.jenvrad.2009.06.002.

Arvela, H., Holmgren, O., Hänninen, P. 2016. Effect of soil moisture on seasonal variation in indoor radon concentration: modelling and measurements in 326 Finnish houses. Radiation Protection Dosimetry 168 (2), 277-290, https:// doi.org/10.1093/rpd/ncv182.

Barnet, I., Pacherová, P., Neznal, M. 2008. Radon in geological environment - Czech experience. Czech Geological Survey, Prague, Czech Geological Survey Special Papers 19, 1-50.
Benavente, D., Valdés-Abellán, J., Pla, C., Sanz-Rubio, E. 2019. Estimation of soil gas permeability for assessing radon risk using Rosetta pedotransfer function based on soil texture and water content. Journal of Environmental Radioactivity 208-209, 105992, https://doi.org/10.1016/j. jenvrad.2019.105992.

Benderev, A., Gerginov, P., Antonov, D., Van Meir, N., Kretzschmar, R. 2015. Conceptual hydrogeological model of the Ogosta river floodplain (Western Balkan, Bulgaria) and its application for predicting of groundwater contamination with arsenic. Proceedings of the $15^{\text {th }}$ International Multidisciplinary Scientific Conference "SGEM2015" 2 (1), 195-202, https://doi.org/10.5593/SGEM2015/B12/S2.026.

Berov, B., Ivanov, P., Frangov, G., Dobrev, N., Krastanov, M. 2017. Liquefaction susceptibility of quaternary deposits in Bulgaria. Proceedings of the $17^{\text {th }}$ International Multidisciplinary Scientific GeoConference "SGEM2017" 17 (12), 499-506, https://doi.org/10.5593/sgem2017/12/ S02.064.

Etiope, G., Martinelli, G. 2000. Migration of carrier and trace gases in the geosphere: an overview. Physics of the Earth and Planetary Interiors 129 (3-4), 185-204, https://doi. org/10.1016/S0031-9201(01)00292-8.

Gerginov, P., Orehova, T., Petrova, V., Antonov, D. 2018. Moisture regime in the upper part of the loess complex in North-Eastern Bulgaria. Review of the Bulgarian Geological Society 79 (3), 139-140.

Ivanova, K., Stojanovska, Z., Kunovska, B., Chobanova, N., Badulin, V., Benderev, A. 2019. Analysis of the spatial variation of indoor radon concentrations (national survey in Bulgaria). Environmental Science and Pollution Research 26 (7), 6971-6979, https://doi.org/10.1007/s11356-01904163-9.

Jönsson, G. 2001. Soil radon depth dependence. Radiation Measurements 34 (1-6), 415-418, https://doi.org/10.1016/ S1350-4487(01)00197-4.

Kolev, S. 2016. Surface-groundwater interaction at the region of Valche dere, downstream of "Eleshnitsa" tailing pond. Proceedings of the National Conference with International Participation “Geosciences 2016”, Abstracts, 153-154 (in Bulgarian, with English abstract). 
Kotsev, T., Stoyanova, V., Aidarova, Z., Genchev, S. 2020. Concept of arsenic monitoring in the soil-groundwaterriver water system in the mining affected Ogosta River Valley. Problems of Geography 1-2, 101-126, https://doi. org/10.35101/prg-2020.1-2.7.

Lucchetti, C., De Simone G., Tuccimei, P., Ricci, T., Finizola, A., Sciarra, A. 2019. Improving gas permeability measurements for environmental monitoring and management. Journal of Waste Management \& Xenobiotics 2 (2), 000123.

Mallants, D., Karastanev, D., Antonov, D., Perko, J. 2007. Innovative in-situ determination of unsaturated hydraulic properties in deep loess sediments in North-West Bulgaria. Proceedings of the $11^{\text {th }}$ International Conference on Environmental Remediation and Radioactive Waste Management “ICEM'07”, 733-739, https://doi.org/10.1115/ ICEM2007-7202.

Nazaroff, W.W., Moed, B.A., Sextro, R.G. 1988. Soil as a source of indoor radon: generation, migration and entry. In: Nazaroff, W.W., Nero, A.V. (Eds), Radon and Its Decay Products in Indoor Air. John Wiley and Sons Inc., New York, 55-112.

Neznal, M., Neznal, M., Matolín, M., Barnet, I., Mikšová, J. 2004. The new method for assessing the radon risk of building sites. Czech Geological Survey Special Papers 16, $48 \mathrm{pp}$.

Neznal, M., Neznal, M. 2005. Permeability as an important parameter for radon risk classification of foundation soils. Annals of Geophysics 48 (1), 175-180, https://doi. org/10.4401/ag-3192.

Nguyen-Tuan, L., Schanz, T., Datcheva, M., Stoimenova, E. 2014. Parameter identification for a thermo-hydro-mechanical model of the buffer material: Stochastic based back analysis. In: Hicks, M.A., Brinkgreve, R.B.J., Rohe, A. (Eds), Numerical Methods in Geotechnical Engineering 1. CRC Press, Taylor \& Francis Group, Boca Raton, London, New York, Leiden, 1001-1006.

Nojarov, P., Stefanov, P., Turek, K. 2020. Influence of some climatic elements on radon concentration in Saeva Dupka Cave, Bulgaria. International Journal of Speleology 49 (3), 235-248, https://doi.org/10.5038/1827-806X.49.3.2349.

Pinault, J.-L., Baubron, J.-C. 1996. Signal processing of soil gas radon, atmospheric pressure, moisture and soil temperature data: a new approach for radon concentration modelling. Geophysical Research Letters 101 (B2), 3157-3171, https://doi.org/10.1029/95JB03121.

Porstendörfer, J. 1994. Properties and behaviour of radon and thoron and their decay products in air. Journal of Aerosol Science 25 (2), 219-263, https://doi.org/10.1016/00218502(94)90077-9.

Rousseva, S. 1997. Data transformations between soil texture schemes. European Journal of Soil Science 48 (4), 749758, https://doi.org/10.1046/j.1365-2389.1997.00113.x.

Rousseva, S. 2001. Parameterization of the hydraulic characteristics of Bulgarian soils. Soil Science Agrochemistry and Ecology 36 (4-6), 48-50 (in Bulgarian, with English abstract).

Sakoda, A., Ishimori, Y., Yamaoka, K. 2011. A comprehensive review of radon emanation measurements for mineral, rock, soil, mill tailing and fly ash. Applied Radiation and
Isotopes 69 (10), 1422-1435, https://doi.org/10.1016/j. apradiso.2011.06.009.

Sapundzhiev, D. 2016. New approaches to the relative assessment (land evaluation) of some basic soil characteristics. Soil Science Agrochemistry and Ecology 50 (3-4), 128-133 (in Bulgarian, with English abstract).

Schanz, T., Datcheva, M., Nguyen-Tuan, L. 2011. Back analysis of a coupled thermo-hydro-mechanical model based on instrumented constant volume column test. In: Papadrakakis, M., Onate, E., Schrefler, B. (Eds), Proceedings of the $I V^{\text {th }}$ International Conference on Computer Methods for Coupled Problems in Science and Engineering, 76-89.

Spassov, V. 1966. Moisture dynamics in the zone of aeration and its effect on the regime and balance of shallow groundwaters. Travaux sur la géologie de Bulgarie, Série Géologie de l'ingénieur et hydrogéologie 5, 45-60 (in Bulgarian, with English abstract).

Spassov, V. 1969. On the total soil moisture potential and methods of its determination. Hydrology and Meteorology 28 (1), 55-61 (in Bulgarian, with English abstract).

Stoyanov, N. 2008. Natural protection from surface pollutants to the Paleogene karst aquifer in the region of Chirpan area "Byalata voda". Part 2. Mathematical model for prognosticating pollutants mass transport in the zone of aeration and in the saturation zone. Annual of the University of Mining and Geology "St Ivan Rilski” 51 (1), 165-171 (in Bulgarian, with English abstract).

Stoyanov, N. 2009. Prognostication of mass-transport of radionuclides in the loess complex in the region of NPS "Kozloduy". Annual of the University of Mining and Geology "St Ivan Rilski” 53 (1), 159-164 (in Bulgarian, with English abstract).

Stoyanov, N. 2012. Model studies estimating the risk of a possible pollution in the geological basis and groundwater caused by the designed National Disposal Facility for Storage of Radioactive Waste in the area of NPS "Kozloduy". Annual of the University of Mining and Geology "St Ivan Rilski" 55 (1), 140-145 (in Bulgarian, with English abstract).

Stoyanov, N. 2018. Modelling the migration of a non-sorbing contaminant in groundwater and soil within industrial sites. Engineering Geology and Hydrogeology 32, 3-11 (in Bulgarian, with English abstract).

Stoynev, S., Ivanov, P. 2019. Historical overview of the cases of soil liquefaction due to earthquakes on the territory of Bulgaria. Review of the Bulgarian Geological Society 80 (3), 221-223 (in Bulgarian, with English abstract).

Tcherkezova, E. 2015. GIS-based delineation and regionalization of geomorphographic units in the floodplain of Ogosta River between the settlement Gavril Genovo and the "Ogosta" reservoir (NW-Bulgaria). Problems of Geography 1-2, 114-122.

Turek, K., Stefanov, P., Orčíková, H. 2020. Radon (Rn-222) concentration in Saeva dupka cave and estimation of effective doses for guides. Problems of Geography 3, 101-117.

Valchev, S., Trayanova, M., Kunovska, B., Mihaylova, B., Mutovska, M. 2020. Analysis of the research activities in Bulgaria related to evaluation of the degree of water saturation in the near-surface layer in connection with the assessment of the radon potential. Review of the Bulgarian Geological Society 81 (3), 233-234. 